Viktoriya Dobrovolska, Doctor of Philosophy in Social Communications, Associate Professor, Associate Professor of the Department of Cultural Studies and Informational Communications National Academy of Managerial Staff of Culture and Arts ORCID: 0000-0002-0927-1179 e-mail: vika_dobrovolska@ukr.net

Yuliya Kalinina-Symonchuk, Head of Legal Support Department V. I. Vernadskyi National Library of Ukraine ORCID: 0000-0002-8936-2926 e-mail: kcyuliya@gmail.com

\title{
CRITERIA AND PRIORITIES FOR SELECTING OBJECTS OF HISTORICAL AND CULTURAL DOCUMENTARY HERITAGE FOR DIGITIZATION
}

The purpose of this work is to identify and generalize the criteria for selecting historical and cultural documentary heritage objects for digitization and further preservation and providing access for users. The research methodology consists of applying general scientific and special methods, in particular, the system approach, analysis, synthesis, logical method, and visualization of research results. The scientific novelty of the work lies in identifying different approaches and a developed system of criteria and priorities, generalizing these criteria for selecting historical and cultural documentary heritage objects for digitization and the conditions to be taken into account, as well as the need for a coordinated position of various departments in this direction, attracting official expertise to determine the sequence and priorities to avoid duplication of digitization. Conclusions. The selection of objects of historical and cultural documentary heritage for digitization is a task that must maintain a balance between the national significance of the funds for the history of national states and the history of mankind, the user's requests and the task of preserving the funds. Digitization offers significant benefits to users of digital cultural resources. The main criteria for selecting objects for digitization are: value, uniqueness, and rarity of documents; documents related to objects of national heritage; documents that have research value; and documents that have an unsatisfactory physical condition; documents that threaten to lose information; documents in high demand and publications that are available in limited quantities. The main goal of selecting cultural heritage objects for digitization is to promote the establishment of Ukrainian identity, the introduction of digital objects of national memory of Ukraine and world heritage into a wide social circulation, and the integration of various Ukrainian digital cultural information resources into a single information system.

Key words: objects of historical and cultural documentary heritage, digitization, digital resources, preservation of cultural heritage. 
Relevance of the research topic. In recent decades, digital technologies have been rapidly developing, entering our daily lives and beginning to transform the information society into a digital one. The introduction of information and communication technologies has helped transform the activities of cultural institutions, in particular archives, libraries, and museums as document and communication structures of society, changing their tasks, functions, and approaches to serving users. The development of information technologies contributed to the emergence of digital technologies and documents in electronic (digital) form, in addition to electronic documents, there were digitized copies of documents, websites, databases, and the like. Millions of documents, museum items, and other intellectual property products are being digitized and organized as public electronic resources around the world.

The purpose of the work is to identify and generalize the criteria for selecting historical and cultural heritage objects for digitization and further preservation and providing access for users.

Analysis of research and publications. A number of scientific works of local researchers is devoted to the problems of selecting objects of historical and cultural documentary heritage for digitization. In particular, the general criteria for selecting documents for digitization of library collections are provided in the works and publications of $\mathrm{H}$. Yevstigneeva [4], H. Kovalchuk [8], K. Lobuzina [12], A. Rybachka [19]. Digital library projects, in particular the organization of long-term preservation of library electronic resources, including digitized ones, are considered in the monograph of I. Lobuzin [11]. Current issues of theory and practice of forming collections of documentary heritage objects-from ancient epigraphic sources to valuable electronic documents of the XXI century are studied by I. Losiyevsky [13]. In the works of L. Dubrovina, the definition of a handwritten book, its identification and attribution is given, the role of library cultural heritage in the system of institutions of national memory of Ukraine, national cultural heritage and its book resource in the era of digital society is highlighted $[2 ; 3]$.

Presentation of the main material. The selection of objects of historical and cultural heritage for digitization in public institutions (libraries, archives, museums) is an important task that should preserve the status of the memorial historical and cultural fund, maintain a balance between the userss requests and the task of preserving the funds.

The main goals of digitizing funds of social memory institutions are as follows: - to allow people, regardless of their location, to directly access, use, and publish various collections of digital materials without visiting the institutions themselves;

- by improving access to their content by providing access to digital surrogates, to ensure the preservation of rare and vulnerable collections, cultural objects; 
- to create a critical array of digital content related to the documentary and cultural heritage of a particular country or region to support research, education, publishing, and exhibition programs;

- attracting new audience and various communities of remote users.

Digitization offers significant benefits to users of digital cultural resources. Thus, stating this, M. Terras summarizes a number of reasons and advantages for implementing a digital project by a cultural institution:

- easier access to content;

- immediate access to high-demand content;

- quick access to materials available elsewhere;

- ability to get unprocessed materials;

- ability to display large maps and visual materials;

- gathering collections that are stored in different locations;

- improving image quality: brightness, color, noise reduction, sharpening, increasing the size, etc.;

- obtaining a digital substitute for brittle material, keeping it at the same time;

- integration of various materials for educational purposes;

- text recognition and enhanced content search capabilities;

- integration of various multimedia resources, such as video, sound and images, etc.

- ability to provide users with digital documents for photocopies or printed prints, etc.

- reducing the cost of document delivery;

- introduction to a wide social circulation of critical information array [30].

The task of selecting cultural objects for digitization is primarily related to the resource and temporary inability of social memory institutions to digitalize all printed materials, manuscripts, audio and video materials, etc. stored in the funds. Therefore, it is important for librarians and information specialists to decide what to select, grant access to them, and save them. It is also worth taking into account the experience of the pan-European digital project Europeanus, which in its strategy for the coming years has identified two main criteria for selecting content: 1) quality instead of quantity, and 2) focusing on user needs [22].

H. Yevstigneeva [4], H. Kovalchuk [10], I. Lobuzina [11] in their works propose to select documents for digitization of library collections according to the following criteria:

- valuable, unique, and rare documents (existing in one or a limited number of copies, including manuscripts and photographs);

- documents related to objects of national heritage, the introduction of which in a wide cultural circulation is of great importance for the restoration of national memory, history and culture of the state; 
- documents of research value;

- documents that are in poor physical condition (damaged due to physical, chemical and biological factors, fragile or oversized documents that require special access conditions), digitization of such documents contributes to their preservation, provided that users have access to their digital copies;

- documents that are at risk of losing information (for example, fading and disappearing text in paper-based documents, demagnetization of records on magnetic tape, loss of color on microforms, while the physical state of the media remains satisfactory, etc);

- documents of high demand and publications available in limited quantities (lowcirculation, destroyed, Prohibited).

The criteria for selecting documents for digitization may also be subordinate to the objectives of a specific digital project or cultural program. Accordingly the selection of materials is critical here and is based on the following facts

- they will be of interest to users in the long term;

- they will acquire new value in digital form;

- they are important for understanding a specific subject area;

- they have artistic value;

- they contain useful or new information;

- they thoroughly cover a specific subject area in a wide and deep way;

- they are important for the subject defined by the project goals;

- they have historical and state value;

- they contain data about objects and groups of objects that are not sufficiently covered in other documents [28].

To determine the category of unique, rare and valuable documents from library, archive and museum collections, libraries of Ukraine should follow the recommendations of the order of the Ministry of Culture of Ukraine on the «Procedure for selecting handwritten books, rare and valuable publications in the State register of national cultural heritage» [18]. According to this order book heritage objects are divided into groups:

1) handwritten books created before the end of the XVII century - all (including fragments), and since the XVIII century - only unique books, taking into account the peculiarities of writing and materials, the place of creation and language, design, content;

2) old printed editions of the XV-XVIII centuries, according to the following groups: incunabula; paleotype; glagolic font edition; Latin font edition; cyrillic font edition; civil font edition; other books (printed in other fonts);

3) Ukrainian publications - books and periodicals printed in the Ukrainian language during the 1801-1922, regardless of what territory they were printed in, printed in any language during the 1801-1860 on the territory of modern Ukraine; 
4) individual valuable publications or copies of publications - the first and/or lifetime editions of the works of the founders of science and technology, containing fundamental scientific discoveries and research; the first and lifetime editions of works of classics of fiction, outstanding figures of culture and art; copies of illegal or censored publications; publishing falsifications and copies with disguised editions; books that are examples of artistic design and printing, including unusual formats and forms; bibliophile publications (numbered or named copies of the publication, reproduced in unusual ways, printed on non-traditional materials, in handmade bindings made of rare materials); copies with autographs, records, ex-libris and seals of prominent figures of the state, science, culture, and literature.

5) Collections - book heritage objects (group code - $\mathrm{CBH}$ ) - collections of individual book heritage objects and/or books and periodicals that together make up a valuable historical and cultural object for the state (world).

H. Kovalchuk [8] sustantiates the inclusion of the book in the category «book heritage object» on the following general grounds:

- chronological (the time when the book was created);

- historical significance of the book for the development of society, region, and the world);

- stages (the book is a heritage object of a critical period in the life of the country, its integral component);

- uniqueness (it distinguishes the book as the only one of its kind that has been preserved in a single copy or has individual features that are of scientific, historical or artistic significance (with autographs, proprietary notes, additional attachments or drawings);

- priority (the book as the first publication of works of classics of science and literature, other works of fundamental importance for history and culture, sociopolitical development);

- memoriality (linking the book with the life and work of outstanding historical personalities or scientific or creative teams, as well as with memorials);

- collectibility (it characterizes the book about its belonging to collections that have the properties of an important historical and cultural object), etc.

The experience of the National Library of Ukraine named after. I. Vernadsky on the formation of the resource of handwritten and book heritage of Ukraine allowed to develop the project «Book heritage objects of the NBUV», which is important for fulfilling the functions of the NBUV as a national library storehouse, related to the implementation of the tasks of forming the State register of national cultural heritage. The database «Book heritage objects of the NBUV» is intended for scientific and bibliographic registration of heritage objects and is currently available on the NBUV portal in the thematic block «Historical and cultural resources». The accumulated information resource about particularly valuable and unique documents

\section{Розділ 6}


of the largest library in Ukraine can be used to form a consolidated database of book heritage objects of other libraries and institutions in Ukraine - museums and archives. This approach reveals the prospects for creating a national digital library, similar to those that are being created in many countries of the world as a priority of state cultural policy [9].

Ukrainian researchers take into account the provisions set out in the interstate standard «Book heritage objects. General requirements», adopted in Ukraine in 2008 [16].

Leading IFLA experts note that the national bibliography is the main source for creating digital library resources. The sources selected for the formation of the national bibliography can be the main reference point for determining the value of publications for digitization [24]. In the National Library of Ukraine named after V. I. Vernadsky powerful electronic resources of the national bibliography were created [12], in particular, the electronic library «Ukrainika» contains full versions of electronic reference books of the national bibliography «Ukrainian-Language book in the NBUV funds, 1798-1923: in 3 vols. (2003)», "Book in Ukraine (1861-1917), in 20 volumes (1996-2017)». The «Digital library of historical and cultural heritage» of NBUV already includes digitized and the first 300 Ukrainian publications according to the list of bibliographic index, starting with the edition «Kotlyarevsky I. P. Eneida translated in Little Russian language, 1798» presented in the collection «Ukrainian-language book (1798-1923)». The significant publications of the national bibliography of Ukraine also include «Repertoire of Ukrainian books, 17981916: vol. 1-9 (1995-2005)» of the Lviv National Scientific Library of Ukraine named after V. Stefanyk and the Institute of Ukrainian Archeography and Source Studies named after M. Hrushevsky (Lviv branch) and «Printed consolidated catalog of Ukrainian-language books of state libraries and museums of Ukraine. 1798-1923. Issue 1-5 (1999-2015) of the Yaroslav the Wise National Library of Ukraine. For more information about the sources of the national bibliography of Ukraine, see the article of the Ukrainian library encyclopedia «Ukrainian bibliographic repertoire» [20].

However, national libraries, archives, museums and other institutions of memory do not only keep books in their collections. A significant part of the library collections is made up of non-book types of documents that are of historical and cultural value and need to be digitized for further preservation and access to the general public. In addition, major libraries in Ukraine are institutions of national significance, and archive materials on their history and the activities of individual departments are stored. In archival institutions and museums, along with documents and other items of the main profile groups, the personal libraries of fund-makers are preserved in full or in fragments. At the same time, the purely archival fund divisions of large libraries also contain significant volumes of book collections and collections that are part of the personal funds of scientists and cultural figures (the Institute of manuscripts 
and the Institute of Archival Studies of the National library of Ukraine named after V. I. Vernadsky). As noted by I. Losiyevsky in the collections of libraries, along with books, there are documents that are not printed and are not directly related to the history of handwritten or printed books, book publishing, among them the researcher specifies the following:

- rare and valuable leafy publications (posters, invitations, postcards, etc);

- rare and valuable music publications;

- rare and valuable cartographic publications;

- archival documents, complexes of archival documents of scientific, historical, cultural, and artistic value: text, image, and text, in particular with seals and stamps;

- photo-, phono-, film, video documents, optical, magnetic disk documents, etc. (they make up collections and collections, archival funds of personal and official origin);

- printed epigraphic heritage objects on various media that represent scientific, historical, cultural, and artistic value: graffiti, ceramic stamps, birch bark certificates, and so on.

- collectible numismatic collections;

- collection of medals;

- collections of award, service and souvenir badges [13].

The general description of cultural heritage is given by the Finnish researcher Hyvönen E.:

- multi-format: cultural objects are represented in various forms, such as text documents, images, audio recordings, videos, collections, learning objects, etc;

- multi-aspect: content covers various topics;

- multilingualism: information is available in different languages;

- multiculturalism: the information is related and interpreted from the point of view of different cultures, religious or national traditions;

- multidirectional: the content of a resource can be targeted at different categories of users [25].

According to the Law of Ukraine «On protection of cultural heritage» (2000) [5], the cultural heritage sites are classified by two main criteria:

- types: structures (works); complexes (ensembles); attractions;

- classes: archaeological; historical; monumental art; architecture and urban planning; garden and park art; landscape; science and technology.

«The procedure for entering unique heritage objects of the Museum Fund of Ukraine in the State register of national cultural heritage» (2002) defines the main criteria for evaluating the value of museum heritage objects:

- origin - definition of the role and significance of attractions, their authors, fundmakers as sources of information, significance of events, phenomena that are 
reflected in heritage objects, their connection with historical events, a certain historical environment, prominent persons, time and place of creation, existence and location;

- content - establishing the meaning of information contained in museum items, identifying the main features that determine the name, authorship, chronology and geography of creation and existence, material and manufacturing techniques, memoriality, repeatability in other heritage objects;

- scientific value - the significance of the heritage object as a source of historical and cultural, natural-scientific and any other information in solving research tasks of the museum;

- artistic value - taking into account the significance of heritage objects, established in the process of identifying their artistic features, the level of artistic quality (features of style, composition, color, originality, manufacturing techniques, general skill of performance);

- external feature-taking into account the originality, presence or absence of inscriptions, signatures, stamps, brands, artistic, paleographic and other features of heritage objects, their physical condition - the degree of preservation, damage, loss [17].

«Methods and criteria for identifying and including unique documentary heritage objects of the National archival Fund of Ukraine in the State register of national cultural heritage» (1998) [14] define the following main provisions:

- a unique documentary heritage object is a particularly valuable document of the National Archive Fund, which is important for the formation of the national identity of the Ukrainian people, determines their contribution to the World cultural heritage, has no analogues and regarding legal force, autograph and external signs can not be restored in the event of irreparable damage or loss.

- criteria of historical and cultural value of documents of the National Archive Fund:

- the value of the funder;

- the authorship of the documents;

- the time when documents were created;

- the value of the displayed information;

- the originality and legal force of documents;

- the presence of artistic features of documents.

It should also be noted that in 2019, a test version of the prototype of the electronic information resource of cultural heritage and cultural values (portal «Cultural heritage of Ukraine») was launched. The resource is available on the website of the Ministry of Culture of Ukraine at the link: https://minkulture.rubycon-test.tk/ The idea of the project is to preserve and promote the cultural heritage of Ukraine at the state level by collecting and accumulating information about cultural heritage 
in electronic form, gradually eliminating paper accounting and introducing electronic accounting of cultural heritage objects and cultural values.

In addition to content and value criteria, researchers also note legal and technical criteria. Legal restrictions and copyrights make up the area that requires constant attention in the digitization process. This is a factor that must be taken into account in the digitization process, in accordance with international recommendations and national legislation. If an institution does not have permission to digitize and publish materials, this may lead to the failure of the entire project. It is important to rely on international publications that consider the issue of copyright comprehensively, for example, "Copyright for librarians» [1]. It is essential for institutions to preserve social memory and cultural heritage to resolve legal issues at the state level related to the possibility of creating digital copies and digital archives for long-term storage of copyrighted documents. An effective solution to this problem, according to international experience, is to extend the legislation on mandatory copies to digital objects [21]. Therefore, an important task is to review the copyright status of the material that is planned to be digitized [26; 27].

It is also necessary to take into account the available technical capabilities of computer and scanning equipment that must be put into operation and configured before starting to deploy a digital project. It is necessary to take into account the formats, sizes, finishes, physical condition of documents and the ability to digitize them with existing equipment, to determine the characteristics and main parameters of the original documents, digital copies of which should be made. These main parameters of originals include: the type of paper and methods of making the original; local disadvantages of originals that require preliminary restoration or further retouching; the tone of the original: dark, light or balanced tone; clarity of the original; overall dimensions of the original. This assessment will determine the selection of hardware for digitizing a specific Fund [23].

An important aspect of selecting documents for digitization is also the presence or absence of metadata that can be used to describe the digital collection. The most common metadata-driven selection defines documents that have a sufficient amount of metadata assigned to them to be in priority. However, you can also select documents that have little or no metadata as an incentive to create metadata and reveal the documentss uniqueness. The availability of metadata can also facilitate previous verification of the existence of a digital copy of the document, possibly made by other institutions, which will prevent duplication of efforts to create digital cultural objects. Such verification should be facilitated by national registers of digital historical and cultural resources [29].

These general approaches should also take into account the national factor of the strategy for forming digitization plans in educational institutions in Ukraine, as well as rely on the expertise of value and cultural significance conducted by

\section{Розділ 6}


leading specialists of libraries, archives, museums [2], take into account the methodological issues of expertise of book and manuscript heritage. In the works of L. Dubrovina, $\mathrm{H}$. Kovalchuk, which provide the basis for determining the handwritten book, their old-printed identification and attribution, the role of the library of cultural heritage in the system of institutions of national memory of Ukraine, national cultural heritage and its unique resource is depicted [2; 7].

It is also necessary to take into account scientific approaches to the state registration of heritage objects, Methodological recommendations for the state registration of heritage objects of interest of Ukraine [15].

Although the issues of expertise are considered to a certain extent in Ukrainian legislation, however, in order to prevent errors of subjectivity, it is important to take into account the experience and authority of scientists recognized by official experts [6].

The scientific novelty of the work consists in identifying different approaches and a developed system of criteria and priorities, generalizing these criteria for selecting historical and cultural documentary heritage objects for digitization and the conditions to be taken into account, as well as the need for a coordinated position of various departments in this direction, attracting official expertise to determine the sequence and priorities to avoid duplication of digitization.

Conclusions. The selection of objects of historical and cultural heritage for digitization is a task that must maintain a balance between the national significance of the funds for the history of the national state and the history of mankind, the user's requests and the task of preserving the funds. Although there are opinions in UNESCO documents on the priorities for the preservation of funds, this balance will help to avoid distortions in the sequence of copying. Digitization offers significant benefits to users of digital cultural resources. The main specific criteria for selecting objects for digitization are as follows: value, uniqueness, and rarity of documents; documents related to objects of national heritage; documents of research value; documents with unsatisfactory physical condition; documents with the threat of loss of information; documents of high demand and publications available in limited quantities. The use of these criteria should also take into account the specifics of the document. A corporate approach to the examination of documents will make this work systematic. The only criterion that is not subject to discussion as a national and historical value, as recognized by all experts both in Ukraine and abroad, is the chronological criterion: for Ukraine, this is all the heritage up to the $17^{\text {th }}$ century, inclusive.

The main goal of selecting cultural heritage objects for digitization is to promote the establishment of Ukrainian identity, the introduction of digital objects of national memory of Ukraine into a wide social circulation, and the integration of various Ukrainian digital cultural information resources into a single information system. 


\section{Список використаних джерел}

1. Авторське право для бібліотекарів: підручник / [пер. з англ. О. Васильєва]. Київ : TOB «IMM «ФРАКCIM», 2015. 196 c.

2. Дубровіна Л. А. Бібліотеки в системі інституцій національної пам'яті України, національної культурної спадщини та її джерельного ресурсу // Рукописна та книжкова спадщина України. 2016. Вип. 20. С. 233-251.

3. Дубровіна Л. А. Книжкові та рукописні фонди бібліотек - культурна спадщина та джерельна база вивчення спільного історичного минулого та міжрегіональної інтеграції в епоху цифрового суспільства (Розділ у кол. монографії). Київ, 2018. C. $160-190$.

4. Евстигнеева Г. А. О критериях комплектования традиционного библиотечного фонда и фонда электронных публикаций в единой системе формирования библиотечно-информационного фонда библиотеки на примере ГПНТБ России // Научные и технические библиотеки. 2010. № 10. С. 23-29.

5. Закон України «Про охорону культурної спадщини». 2000. URL: https://zakon. rada.gov.ua/laws/show/1805-14

6. Калініна-Симончук Ю. С. Експертиза цінності рукописної та книжкової спадщини в законодавстві України: сучасний стан та перспективи розвитку // Рукописна та книжкова спадщина України. 2019. Вип. 24. С. 268-280. URL: http://rksu.nbuv.gov. ua/doc/rks_2019_24_19

7. Ковальчук Г. Експертиза книжкових памэяток у бібліотеках: Українознавчий аспект // Україна: культурна спадщина, національна свідомість, державність. 2012. № 21. С. 403-416.

8. Ковальчук Г. І. Критерії відбору книжкових пам'яток для першочергового поцифрування // Наукові праці Національної бібліотеки України імені В. І. Вернадського. 2010. Вип. 28. С. 141-147.

9. Ковальчук Г. І., Лобузіна К. В. Проблеми створення інтегрованого веб-ресурсу книжкових пам'яток України. Матеріали III Міжнародних книгознавчих читань «Стародруки і рідкісні видання в університетській бібліотеці» (Одеса, 15-17 вересня 2015 р.). Одеса, 2016. С. 8-17.

10. Ковальчук Г. Рідкісні українські книги в бібліотечних фондах: пам'яткознавчий аспект // Бібліотечний вісник. 2007. № 5. С. 29-36.

11. Лобузін І. Цифрові бібліотечні проекти: технологічні рішення та управління життєвим циклом колекцій : монографія. Київ, 2016. 216 с.

12. Лобузіна К. Інформаційні технології створення національних бібліографічних ресурсів // Бібліотечний вісник. 2013. № 1. С. 9-14. URL: http://nbuv.gov.ua/UJRN/ bv_2013_1_2

13. Лосієвський І. Я. Документні пам'ятки в бібліотечних зібраннях: теоретикометодологічні аспекти та сучасна практика // Вісник Харківської державної академії культури. 2013. Вип. 41. С. 124-134.

\section{Розділ 6}


14. Методика і критерії виявлення і включення унікальних документальних пам'яток Національного архівного фонду України до Державного реєстру національного культурного надбання / Головне архівне управління України ; Національна академія наук України. Київ, 1998. URL: https://zakon.rada.gov.ua/laws/show/z0801-98

15.Методичні рекомендації для Державної реєстрації книжкових пам'яток України. Кириличні рукописні книги та стародруки. Принципи реєстраційного опису / укл. Л. А. Дубровіна та ін. Київ, 2007. 134 с.

16. Міждержавний стандарт: ДСТУ: ГОСТ 7.87:2008 Система стандартів 3 інформації. бібліотечної та видавничої справи. Книжкові пам'ятки. Загальні вимоги (ГОСТ 7.87-2003. IDT). - Див. ГОСТ 7.87-2003 «Книжные памятники. Общие сведения».

17. Порядок занесення унікальних пам'яток Музейного фонду України до Державного реєстру національного культурного надбання. Наказ МОН України. 2002. URL: https//zakon.rada.gov.ua/laws/show/z0144-02

18. Про затвердження Порядку відбору рукописних книг, рідкісних і цінних видань до Державного реєстру національного культурного надбання. 2016. § 437. Розд. II. Ст. 1-3. URL: https://zakon.rada.gov.ua/laws/show/z0936-16

19. Рибачок О.М. Міжнародні інтегровані цифрові ресурси документальної спадщини архівів, бібліотек, музеїв: етапи створення, стратегії розвитку (80-ті роки XX - 10-ті роки XXI ст.) : дис... канд. іст. наук (доктора філософії) за спеціальністю 27.00.02 «Документознавство, архівознавство» / Національна бібліотека України імені В. І. Вернадського. Київ, 2018. 242 с.

20. Український бібліографічний репертуар. Українська бібліотечна енциклопедія. URL: http://ube.nlu.org.ua/article/\%D0\%A3\%D0\%BA\%D1\%80\%D0\%B0\%D1\% 97\%D0\%BD\%D1\%81\%D1\%8C\%D0\%BA\%D0\%B8\%D0\%B9\%20\%D0\%B1\%D1\%96\% D0\%B1\%D0\%BB\%D1\%96\%D0\%BE\%D0\%B3\%D1\%80\%D0\%B0\%D1\%84\%D1\%96\%D1\%87\%D0\%BD\%D0\%B8\%D0\%B9\%20\%D1\%80\%D0\%B5\%D0\%BF\%D0\%B5\%D1\%80\%D $1 \% 82 \% \mathrm{D} 1 \% 83 \% \mathrm{D0} \% \mathrm{~B} 0 \% \mathrm{D} 1 \% 80$

21. Dobrovolska Viktoriya. Preservation of the digital cultural heritage: basic problems, tasks, principles of selection. Social and Human Sciences. Polish-Ukrainian scientific journal, 2019. 03 (23). Available at: https://sp-sciences.io.ua/s2663927/ dobrovolska_viktoriya_2019_._preservation_of_the_digital_cultural_heritage_basic_ problems_tasks_principles_of_selection._social_and_human_sciences._polishukrainian_scientific_journal_03_23_

22. Europeana content strategy: Getting the right content to the right user at the right time. 2017. URL: https://pro.europeana.eu/files/Europeana_Professional/ Publications/Europeana\%20Content\%20Strategy.pdf

23. Guidelines for digitization projects for collections and holdings in the public domain, particularly those held by libraries and archives. IFLA ; UNESCO. 2003. URL: http://archive.ifla.org/VII/s19/pubs/digit-guide.pdf.

24. Guidelines for National Bibliographies in the Electronic Age. IFLA. 2008. URL: https://archive.ifla.org/VII/s12/guidelines-national-bibliographies-electronic-age.pdf 
25. Hyvönen E. (2012). Publishing and Using Cultural Heritage Linked Data on the Semantic WebPublishing and Using. Synthesis lectures on the semantic web: theory and technology, \#3, 1-145. URL: https://seco.cs.aalto.fi/publications/2012/hyvonen-chbook-2012.pdf.

26. Johansson S. Who has the power over cultural heritage? A case study of digitization selection criteria used at Kungl. Biblioteket. Master's thesis Swedish school of library and information science. 2014. 70 p. URL: http://www.diva-portal.org/smash/get/ diva2:1310166/FULLTEXT01.pdf.

27. Peter B. Hirtle, Emily Hudson, and Andrew T. Kenyon. Copyright and Cultural Institutions Guidelines for Digitization for U.S. Libraries, Archives, and Museums. Cornell University Library, Ithaca, New York, 2009.

28. Nacionalni projekt «Hrvatska kulturna baština» 2007. Smjernice za odabir građe zadigitalizaciju. URL: http://www.kultura.hr/hr/content/download/596/7925/file/ smjernice_odabir.pdf

29. Ooghe B. and Dries M. Analysing Selection for Digitisation: Current Practices and Common Incentives. D-Lib Magazine, 15, N 9/10. URL: http://www.dlib.org/dlib/ september09/ooghe/09ooghe.html.

30. Terras M. Digital Images for the Information Professional. Burlington, VT: Ashgate, 2008. 245 p.

\section{Вікторія Василівна Добровольська,}

кандидат наук із сочіальних комунікацій, дочент,

дочент кафедри культурології та інформачійних комунікацій

Національної академії керівних кадрів культури і мистецтв

ORCID: 0000-0002-0927-1179

e-mail: vika_dobrovolska@ukr.net

\section{Юлія Сергіївна Калініна-Симончук,}

начальник відділу правового забезпечення діяльності

Національної бібліотеки України імені В. І. Вернадського

ORCID: 0000-0002-8936-2926

e-mail:kcyuliya@gmail.com

Критерії та пріоритети відбору об'єктів історико-культурної документальної спадщини для оцифрування

Мета роботи - виявити та узагальнити критерії відбору об'єктів історикокультурної документальної спадщини для оцифрування та подальшого їх збереження й забезпечення доступу для користувачів. Методологія дослідження полягає в застосуванні загальнонаукових і спеціальних методів, зокрема системного підходу, аналізу, синтезу, логічного методу, методу візуалізації результатів дослідження. Наукова новизна роботи полягає у виявленні різних підходів та розвинутої системи критеріїв і пріоритетів; узагальненні цих критеріїв відбору об'єктів історико- 
культурної документальної спадщини для оцифрування та умов, які потрібно враховувати; необхідності узгодженої позиції різних відомств у цьому напрямі; залученні офіційної експертизи для визначення послідовності та пріоритетів для уникнення дублювання оцифрування. Висновки. Відбір об'єктів історико-культурної документальної спадщини для оцифрування $\epsilon$ завданням, яке має підтримати баланс між національним значенням фондів для історії національних держав та історії людства, запитами користувача та завданням збереження фондів. Оцифрування надає значних переваг користувачам цифрових культурних ресурсів. Основними критеріями відбору об'єктів для оцифрування є: цінність, унікальність, рідкісність документів; документи, що відносяться до об'єктів національного надбання; документи, що мають дослідницьку цінність; документи, які мають незадовільний фізичний стан; документи, що мають загрозу втрати інформації; документи підвищеного попиту та видання, наявні в обмеженій кількості. Головною метою відбору об'єктів культурної спадщини для оцифрування $\epsilon$ сприяння утвердженню української ідентичності, введенню в широкий соціальний обіг цифрових об'єктів національної пам'яті України та спадщини світу, інтеграції різних українських цифрових культурних інформаційних ресурсів в єдину інформаційну систему.

Ключові слова: об'єкти історико-культурної документальної спадщини, оцифрування, цифрові ресурси, збереження культурної спадщини.

Стаття підготовлена 2 березня 2020 року; подана до друку 20 березня 2020 року. 